\title{
Effect of viscosity on heat transfer in nanoparticles
}

\author{
Khandan Roshanaei ${ }^{1}$, Edip Taşkesen ${ }^{2 *}$, Mehmet Özkaymak ${ }^{3}$ \\ ${ }^{1}$ Energy Systems Engineering Department, Karabuk University, Karabuk, Turkey, (ORCID: 0000-0002-1469-8812), khandan.roshanaei@gmail.com \\ $2^{*}$ Energy Systems Engineering Department, Sirnak University, Sirnak, Turkey, (ORCID: 0000-0002-3052-9883), ediptaskesen@gmail.com \\ ${ }^{3}$ Energy Systems Engineering Department, Karabuk University, Karabuk, Turkey, (ORCID: 0000-0002-4575-8988), mozkaymak@gmail.com
}

(1st International Conference on Applied Engineering and Natural Sciences ICAENS 2021, November 1-3, 2021)

(DOI: 10.31590/ejosat.996917)

ATIF/REFERENCE: Roshanaei, K., Taşkesen, E. \& Özkaymak, M. (2021). Effect of viscosity on heat transfer in nanoparticles. European Journal of Science and Technology, (28), 259-262.

\begin{abstract}
In our research, it has been concluded that there are various utilizing areas for Nano-fluids in industrial fields in solar energy systems and even thermal systems. The demotion of the particles in Nano-fluids as nonmetric size should vary between one to one hundred nanometers in the basic fluids. In this work, Nano-fluids usage in cooling or chilling and even heating and their usage districts were explored. Due to the researches, we identified that thermal conductivity's efficiency affects of the differences of the Nano-fluids with different aspects.
\end{abstract}

Keywords: Nano fluids, Heat Transfer, Nanoparticle, viscosity, thermal conductivity.

\section{Nanopartiküllerde viskozitenin ısı transferine etkisi}

$\ddot{O} \mathbf{z}$

Araştırmamızda, güneş enerjisi sistemlerinde ve hatta termal sistemlerde endüstriyel alanlarda Nano-akışkanların çeşitli kullanım alanlarının olduğu sonucuna varılmıştır. Nano-akışkanlardaki partiküllerin metrik olmayan boyut olarak indirgenmesi, temel akışkanlarda yüz nanometre arasında değişmektedir. Bu çalışmada Nano-akışkanların soğutma veya soğutma ve hatta 1sıtmada kullanımı ve kullanım alanları araştırılmıştır. Yapılan araştırmalar sonucunda 1sıl iletkenliğin veriminin Nano-akışkanların farklılıklarından farklı açılardan etkilendiğini tespit edilmiştir.

Anahtar Kelimeler: Nano akışkanlar, Isı Transferi, Nanopartikül, viskozite, termal iletkenlik. 


\section{Introduction}

One of the most important topics in engineering is being the cost-effectiveness in products.

Due to basic Natural science, there are various types of colloidal. Moreover the important point in colloidal is their article which include clusters and Pickering emulsions [1,2]. Most of the times the nanoparticles are dispersed in a liquid base fluid. Although essentially the word 'Nano fluid' approved by Choi in International mechanical engineering congress and exhibition, San Francisco, 1995 [3]. Illustrative figures below in Figure 1 demonstrate the solid nanostructured materials with various properties.

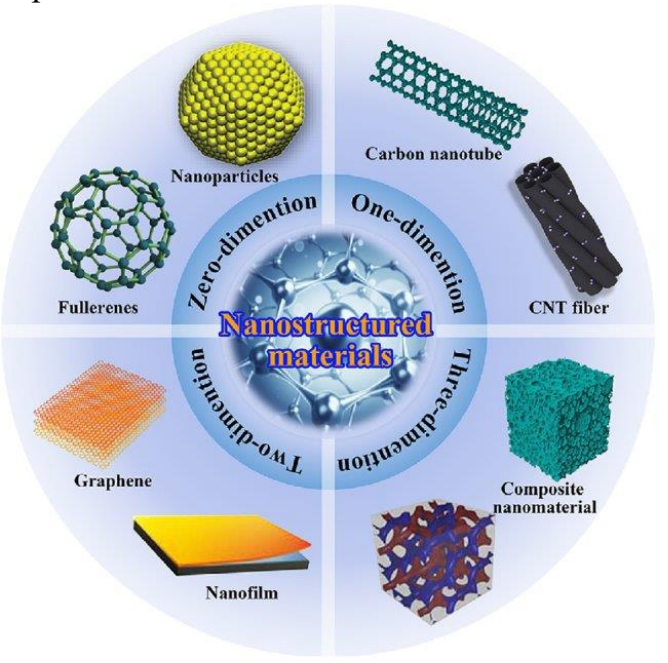

Fig. 1. Divergent construction of Nanomaterials[4-6].

The characters of nanoparticles are commented with their amount of surfaces and not their mass or weight and bulk [7]. The nature of nanoparticles leads them to possess appropriate thermal, electrical, biological, optical and catalytic properties, better performance and conduct them to be practical in various heat transfer engineering applications [8]. As it can be easily understood from figure 3, the heat conduction of Nano-fluids affects by different factors such as size, shape, thermal conductivity and temperature [9]. Even in Figure 3 the grain size, boundary, surface interactions, doping and temperature results on Nano-fluids has been depicted.

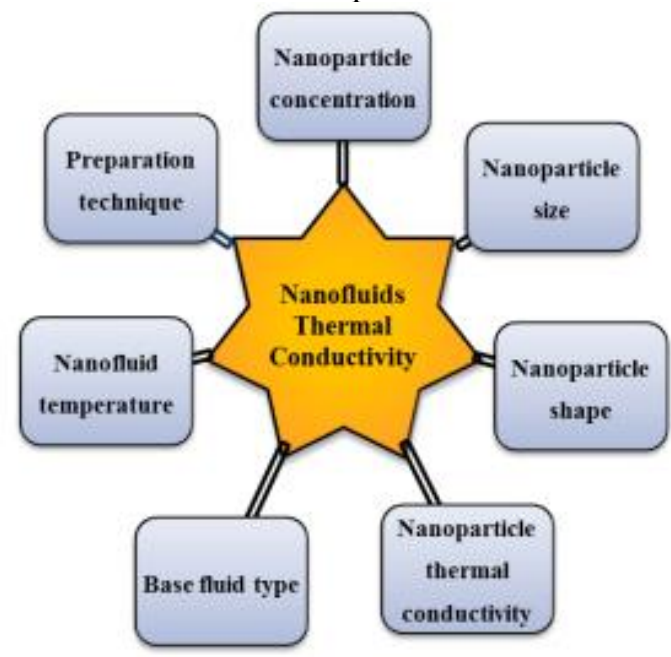

Fig. 2. The most effective thermal conductivity parameters on Nano-fluids [9].

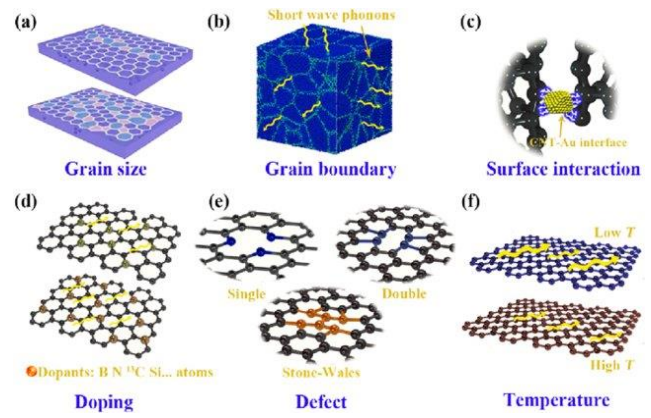

Fig. 3. Grain size, grain boundary, surface interaction, doping, defect, and temperature effects on thermal conductivity of Nano fluids [10].

Also various items are effective in the heat transfer of Nano fluids that are called Thermo-physical properties: such as the geometry of the Nano fluids, the structure of the base fluid, and the boundary conditions of fluids. Figure 4 reveals the ubiquitous usage of Nano materials.
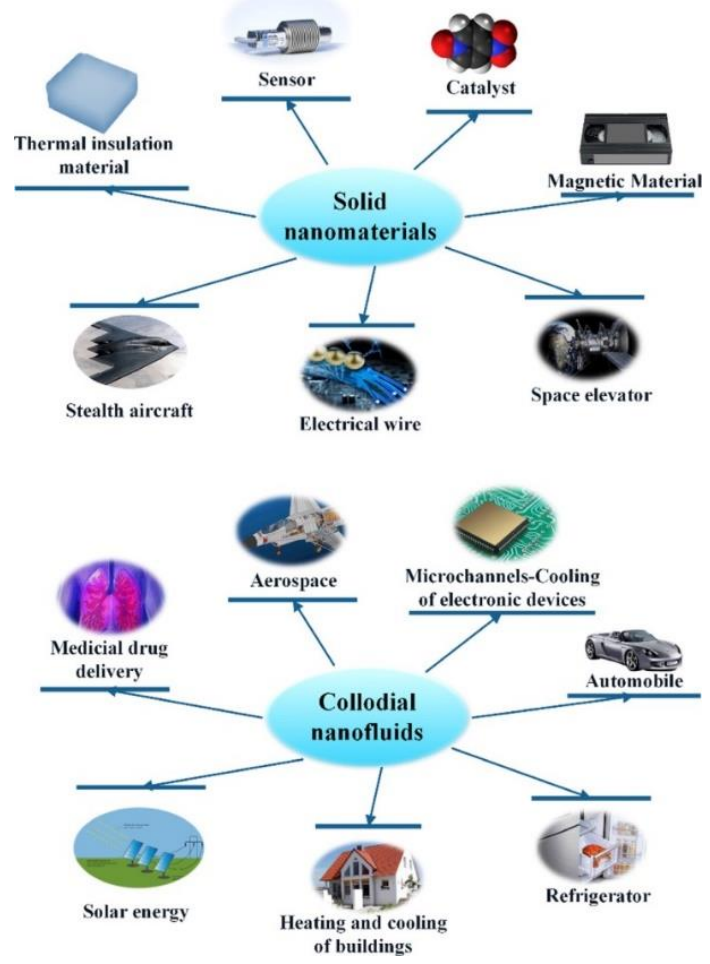

Fig. 4. Application of Nanomaterials and Nano fluids [8,11].

\section{Material and Method}

The physical properties such as thermal conductivity and viscosity are vital parameters to explore the possibility for heat transfer enhancement of passing and circulating fluid [12].

Mainly there are two procedures for the preparation of Nano fluids:

Single-step method and two-step method [13]. Figure 5 shows two different methods for the preparation of the Nano fluids. 


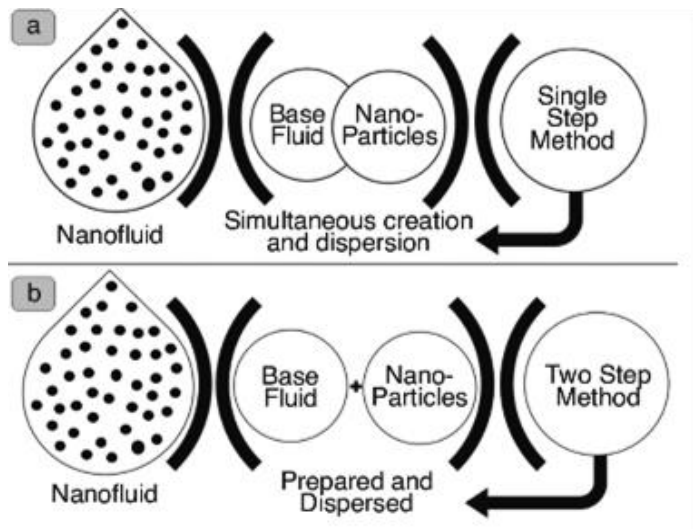

Fig. 5. Different methods of preparation Nano fluids [14,15].

In the singe-step technique, the generating of nanoparticles follows the production of Nano-fluids. Vapour deposition, submerged arc and chemical depletion are mainly used in singlestep methods. Even, generally two-step methods used to produce Nano fluids for heat transfer. Furthermore, in two-step methods the process of the nanoparticles and Nano fluids is executed separately [12]. Also the improvement of thermal conductivity of Nano fluids while their working time would be the most logical way to boost their efficiency. In addition the various types of Nano fluids have expanded in the past couple of decades. Viscosity is one of the most important factors that regulate the skin fraction coefficient of the fluid [16], pressure reduction in the thermal system. As mentioned before viscosity effect the velocity of Nano fluids continuously the temperature characteristic of the heat transfer [17]. Parallel to the thermal conductivity, other factors such as size, dimension, shape, temperature, $\mathrm{PH}$ value, particle concentration and surfactant are effective in this issue. Due to scientific researches dynamic viscosity such as thermal conductivity is one of the key factors in Nano fluids[18]. The viscosity templates and even formulas contemplated the concentration of nanoparticles as a key that indicates the effectiveness of Nano fluids viscosity. Figure 6 demonstrates the most important factor on the viscosity of the fluids; here especially $\mathrm{TiO} 2$ as Nano fluid has been selected.

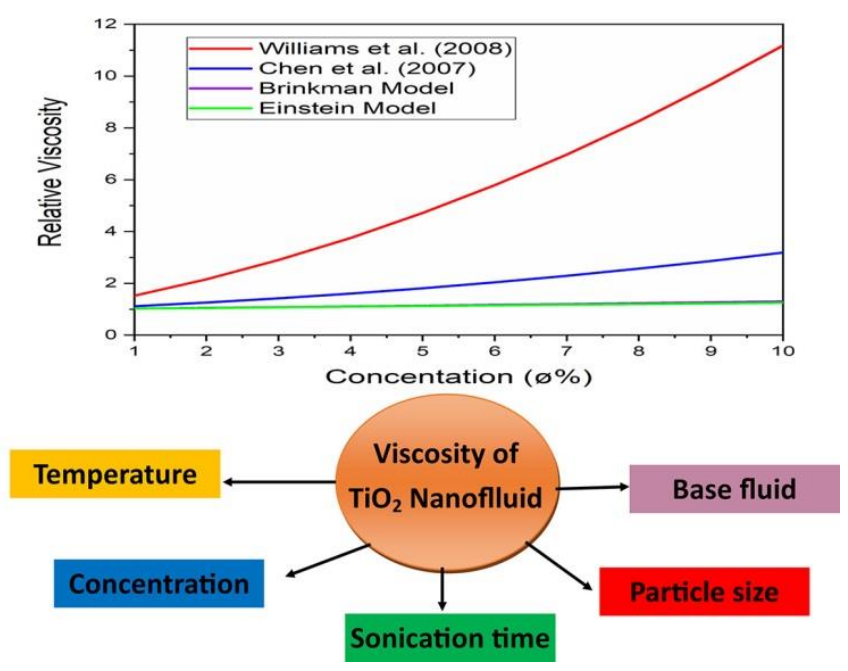

Fig. 6. Effective parameters on Viscosity of sample Nano fluid $\mathrm{TiO}_{2}$ [19].

\section{Conclusions and Recommendations}

The following results are obtained by using Nano fluid.

- It has been observed that adding nanoparticles into the basic fluid as pure water increases the amount of heat transfer by the convection method.

- According to the Thermo physical properties of the Nano fluid, viscosity differed and consequently, it affected the heat transfer.

- With increasing the efficiency of heat transfer consequently, the Nano fluid morphological structure would be changed.

- The usage of Nano fluid in the industry has been widespread recently.

\section{References}

[1] [Dinsmore, A. D., Hsu, M. F., Nikolaides, M. G., Marquez, M., Bausch, A. R., and Weitz, D. A., "Colloidosomes: selectively permeable capsules composed of colloidal particles", Science, 298 (5595): 1006-1009 (2002).

[2] Kim, S.-H., Yi, G.-R., Kim, K. H., and Yang, S.-M., "Photocurable Pickering emulsion for colloidal particles with structural complexity", Langmuir, 24 (6): 2365-2371 (2008).

[3] Choi, S. U. S. and Eastman, J. A., "Enhancing thermal conductivity of fluids with nanoparticles", Argonne National Lab., IL (United States), (1995).

[4] Qiu, L., Zou, H., Tang, D., Wen, D., Feng, Y., and Zhang, X., "Inhomogeneity in pore size appreciably lowering thermal conductivity for porous thermal insulators", Applied Thermal Engineering, 130: 1004-1011 (2018).

[5] Vukovic, I., ten Brinke, G., and Loos, K., "Block copolymer template-directed synthesis of well-ordered metallic nanostructures", Polymer, 54 (11): 2591-2605 (2013).

[6] Mariscal, M. M., Olmos-Asar, J. A., Gutierrez-Wing, C., Mayoral, A., and Yacaman, M. J., "On the atomic structure of thiol-protected gold nanoparticles: a combined experimental and theoretical study", Physical Chemistry Chemical Physics, 12 (37): 11785-11790 (2010). 
[7] Yonezawa, T., "Preparation of metal nanoparticles and their application for materials", Nanoparticle Technology Handbook, Elsevier, 829-837 (2018).

[8] Qiu, L., Zhu, N., Feng, Y., Michaelides, E. E., Żyła, G., Jing, D., Zhang, X., Norris, P. M., Markides, C. N., and Mahian, O., "A review of recent advances in thermophysical properties at the nanoscale: From solid state to colloids", Physics Reports, 843: 1-81 (2020).

[9] Tawfik, M. M., "Experimental studies of nanofluid thermal conductivity enhancement and applications: A review", Renewable And Sustainable Energy Reviews, 75: 1239-1253 (2017).

[10] Qiu, L., Zou, H., Wang, X., Feng, Y., Zhang, X., Zhao, J., Zhang, X., and Li, Q., "Enhancing the interfacial interaction of carbon nanotubes fibers by $\mathrm{Au}$ nanoparticles with improved performance of the electrical and thermal conductivity", Carbon, 141: 497-505 (2019).

[11] Tekir, M., Taskesen, E., Aksu, B., Gedik, E., and Arslan, K., "Comparison of bi-directional multi-wave alternating magnetic field effect on ferromagnetic nanofluid flow in a circular pipe under laminar flow conditions", Applied Thermal Engineering, 179: 115624 (2020).

[12] Yang, L., Xu, J., Du, K., and Zhang, X., "Recent developments on viscosity and thermal conductivity of nanofluids", Powder Technology, 317: 348-369 (2017).

[13] Yang, L., Du, K., Bao, S., and Wu, Y., "Investigations of selection of nanofluid applied to the ammonia absorption refrigeration system", International Journal Of Refrigeration, 35 (8): 2248-2260 (2012).

[14] Babar, H., Sajid, M. U., and Ali, H. M., "Viscosity of hybrid nanofluids: a critical review", Thermal Science, 23 (3 Part B): 1713-1754 (2019).

[15] Ali, H. M., Babar, H., Shah, T. R., Sajid, M. U., Qasim, M. A., and Javed, S., "Preparation techniques of TiO2 nanofluids and challenges: a review", Applied Sciences, 8 (4): 587 (2018).

[16] Tamim, H., Dinarvand, S., Hosseini, R., Rahimi, H., and Pop, I., "Steady laminar mixed convection stagnation-point flow of a nanofluid over a vertical permeable surface in the presence of a magnetic field", Journal Of Applied Mechanics And Technical Physics, 57 (6): 1031-1041 (2016).

[17] Dinarvand, S., Hosseini, R., and Pop, I., "Homotopy analysis method for unsteady mixed convective stagnation-point flow of a nanofluid using Tiwari-Das nanofluid model", International Journal Of Numerical Methods For Heat \& Fluid Flow, (2016).

[18] Alawi, O. A., Sidik, N. A. C., Xian, H. W., Kean, T. H., and Kazi, S. N., "Thermal conductivity and viscosity models of metallic oxides nanofluids", International Journal Of Heat And Mass Transfer, 116: 1314-1325 (2018).

[19] Abdullah, A. M., Chowdhury, A. R., Yang, Y., Vasquez, H., Moore, H. J., Parsons, J. G., Lozano, K., Gutierrez, J. J., Martirosyan, K. S., and Uddin, M. J., "Tailoring the viscosity of water and ethylene glycol based TiO2 nanofluids", Journal Of Molecular Liquids, 297: 111982 (2020). 